\title{
Fatty-acid-binding protein as a plasma marker for the estimation of myocardial infarct size in
} \section{humans}

Jan F C Glatz, Appie H Kleine, Frans A van Nieuwenhoven, Wim T Hermens, Marja P van Dieijen-Visser, Ger J van der Vusse

\begin{abstract}
Background-There are substantial amounts of cytoplasmic heart-type fattyacid-binding protein (FABP) $(15 \mathrm{kDa})$ in myocardial tissue. The rapid release of FABP into plasma during ischaemia indicates the possibility of using this protein as a biochemical marker for ischaemic myocardial injury.
\end{abstract}

Objective-To study the completeness of the release of FABP from damaged tissue in patients with acute myocardial infarction (AMI) and the suitability of serial plasma FABP concentrations for estimation of myocardial infarct size.

Methods-Immunochemically assayed FABP and enzymatically assayed creatine kinase isoenzyme MB (CK-MB) and $a$-hydroxybutyrate dehydrogenase (HBDH) were determined serially in plasma samples from 49 patients with AMI who had been treated with thrombolytic agents within six hours after the onset of AMI. Previously validated circulatory models and a value of $2.6 \mathrm{~h}^{-1}$ for the fractional clearance rate of FABP from plasma were used to calculate cumulative protein release into plasma.

Results-Release of FABP was completed earlier (24-36 h) after AMI than that of CK-MB (50-70 h) and that of HBDH (> $70 \mathrm{~h})$. However, infarct size estimated from the cumulative release of the proteins and expressed as gram equivalents of healthy myocardium per litre of plasma yielded a comparable value of 4-6 for both FABP and the two enzymes. Conclusion-The data indicate that FABP released from the heart after AMI is quantitatively recovered in plasma and that FABP is a useful biochemical plasma marker for the estimation of myocardial infarct size in humans.

(Br Heart f 1994;71:135-140)

Acute myocardial infarction (AMI) in humans is usually assessed or excluded by the measurement in plasma of the activities of cardiac enzymes, such as creatine kinase isoenzyme MB (CK-MB) and $a$-hydroxybutyrate dehydrogenase $(\mathrm{HBDH})^{12}$ or of the concentrations of cardiac proteins such as myoglobin $^{34}$ and tropinin T.56 Because Myoglobin appears in substantial quantities in plasma within $2-3 \mathrm{~h}$ of the onset of $\mathrm{AMI}$, whereas other proteins take at least four hours, it has been suggested that myoglobin may be a biochemical marker that is especially suitable for the early assessment of $\mathrm{AMI},{ }^{78}$ and may also allow reperfusion to be distinguished from persistent occlusion after thrombolytic therapy. ${ }^{910}$ In addition, both cardiac enzymes and myoglobin released from the heart after AMI are completely recovered in plasma. ${ }^{112}$ Hence the cumulative release of each of these markers can be used to estimate infarct size in gram equivalents of healthy myocardium per litre of plasma.

Recently, another cardiac protein, hearttype fatty-acid-binding protein (FABP), has been proposed as an early plasma marker for AMI. ${ }^{13-15}$ This small $(15 \mathrm{kDa})$ cytoplasmic protein is abundant in cardiomyocytes and is thought to be involved in myocardial lipid homoeostasis. ${ }^{16}{ }^{17} \mathrm{We}^{18}$ and others ${ }^{19}$ found that FABP is released in substantial amounts from human hearts after AMI and that, like myoglobin, plasma FABP concentrations are increased considerably within three hours of AMI and return to normal within 24 hours. It is not yet known, however, whether all FABP is released from damaged tissue and whether this protein too can be used as biochemical marker to estimate the size of myocardial infarcts.

We compared the release of FABP, CK$M B$, and $\mathrm{HBDH}$ into plasma after AMI and estimated infarct size from the corresponding plasma curve areas.

\section{Patients and methods}

PATIENTS AND BLOOD SAMPLING

We studied 50 patients (six women, 44 men; age 29-71) with chest pain and ST segment elevation typical of AMI. Patients were eligible for this study if they were admitted to the coronary care unit of the hospital within six hours after the first onset of infarct-related symptoms. Patients were participating in a pilot study of treatment with a new inhibitor of platelet function by selective blockade of thromboxane $\mathrm{A}_{2}$ synthetase (Ridogrel, Janssen Pharmaceutics, Beerse, Belgium) and were also treated with alteplase (Boehringer Ingelheim, Germany) and heparin. Coronary angiography, performed at 90 minutes after start of treatment, showed successful reperfusion in $\mathbf{4 0}$ patients. Subsequent percutaneous transluminal coronary angioplasty (PTCA), in the remaining cases also showed reperfusion. Ischaemia was located anteriorly in 13 patients and inferioposteriorly in 37 patients. 
None of the patients had cardioversion. Plasma samples were incomplete for one patient who died: the results of the remaining 49 patients are shown. Further details on patient selection and clinical treatment are described elsewhere. ${ }^{20}$

Blood samples were taken upon admission to the hospital $(2 \cdot 8(1 \cdot 3) \mathrm{h}$, range $1 \cdot 1-6 \cdot 0 \mathrm{~h})$ after the onset of symptoms mean (SD) for $\mathrm{n}=$ 49 ) and 3, 6, 9, 12, 24, 36, 48, 72, and (for 35 patients only) $96 \mathrm{~h}$ thereafter, resulting in nine or 10 samples per patient. Samples were collected in glass tubes containing dry heparin. After routine centrifugation plasma was stored in several aliquots at $-20^{\circ} \mathrm{C}$ until analysis.

\section{ANALYTICAL TECHNIQUES}

FABP was measured in plasma and tissue samples by a sensitive non-competitive enzyme-linked immunosorbent assay of the antigen capture type (sandwich ELISA) as described elsewhere. ${ }^{18}$ Samples were diluted with phosphate buffered saline ( $\mathrm{pH} \mathrm{7.4)}$ containing $0.1 \%$ bovine serum albumin and $0.05 \%$ Tween-20. The detection limit of the assay was $0.5 \mu \mathrm{g} / 1$. The recovery (mean (SD)) of purified human heart FABP added in various quantities to control human plasma was $94(12) \%(n=11)$ and the interassay coefficient of variation was $6 \cdot 5 \%$.

The activities of creatine kinase isoenzyme $\mathrm{MB}(\mathrm{CK}-\mathrm{MB})$ and $\mathrm{HBDH}$ were measured spectrophotometrically at $25^{\circ} \mathrm{C}$ in a centrifugal analyser (Cobas Bio System, Hoffmann La Roche, Basel, Switzerland) with commercially available test kits. For CK-MB we used an enzyme assay kit that is based on immunoinhibition of the predominant $M$ unit in creatine kinase (Boehringer Mannheim, Germany). For HBDH, which reflects mainly the activity of lactate dehydrogenase isoenzyme-1, we used an assay kit with 2oxobutyrate as the substrate (Boehringer Mannheim, Germany). Activities are expressed in $\mu \mathrm{mol}$ substrate converted per minute (units) per litre of plasma.

\section{PLASMA REFERENCE VALUES}

Reference values (upper normal concentration or activity) for FABP, CK-MB, and $\mathrm{HBDH}$ in plasma were estimated in nonhaemolytic blood samples obtained from 72 healthy blood donors. Mean (SD) plasma FABP concentration was 9 (5) $\mu \mathrm{g} / 1, \mathrm{CK}-\mathrm{MB}$ activity 4 (3) $\mathrm{U} / 1$, and $\mathrm{HBDH}$ activity 90 (35)U/l. The reference values (mean plasma concentration or activity plus twice the standard deviation) were $19 \mu \mathrm{g} / 1$ for FABP, $10 \mathrm{U} / 1$ for $\mathrm{CK}-\mathrm{MB}$, and $160 \mathrm{U} / \mathrm{l}$ for $\mathrm{HBDH}$.

\section{CALCULATION OF CUMULATIVE PROTEIN}

\section{RELEASE}

Cumulative release of cardiac proteins from the onset of AMI ( $t=0)$ up to time $t, Q(t)$, was calculated for a two-compartment model $^{21}$ as follows:

$Q(t)=C(t)+\operatorname{TER} \int_{0}^{t} \exp [\operatorname{ERR}(\tau-t)] C(\tau) d \tau+F C R \int_{0}^{t} C(\tau) d \tau$ where the three terms are the actual protein concentration (or enzyme activity) in plasma, the extravascular concentration, and the amount of protein eliminated from plasma, respectively, each expressed per litre of plasma. TER, ERR, and FCR are the fractional rate constants for transcapillary escape, extravascular return, and catabolism (elimination) of protein, respectively.

For CK-MB the values used were: TER = $0.014 \mathrm{~h}^{-1}, \mathrm{ERR}=0.018 \mathrm{~h}^{-1}$, and FCR $=0.34$ $\mathrm{h}^{-1} .^{1}{ }^{21}$ For $\mathrm{HBDH}$ the values for TER and ERR were equal to those of CK-MB, whereas FCR was $0.015 \mathrm{~h}^{-1}$. $^{21}$

Calculation of the cumulative release of FABP was hampered by the fact that its fractional clearance rate is not known. However, turnover studies in humans of other small proteins such as myoglobin $(17 \cdot 2 \mathrm{kDa}),{ }^{22}{ }^{23}$ lysozyme $(14 \mathrm{kDa})^{24}$ and retinol binding protein $(21 \mathrm{kDa})^{25}$ all showed elimination from plasma predominantly by rapid renal clearance with a half life of $10-20 \mathrm{~min}$. Hence the cumulative release of myoglobin into plasma after AMI was calculated in a onecompartment (that is plasma volume) model ${ }^{12}{ }^{26}$ where the second term in the above formula was left out, so that the cumulative protein release equals the integrated plasma curve, multiplied by FCR. Because the mean half life of myoglobin in AMI patients is 16 $\min ^{23}$ the FCR amounts to (ln 2$) /\left(t_{1 / 2}\right)=$ $2 \cdot 6 \mathrm{~h}^{-1}$. This approach was validated in a separate set of 10 patients with clinically confirmed AMI in whom plasma samples were taken every hour (fig 1). The ratio of the plasma concentrations of myoglobin and FABP remained constant throughout the period that plasma values were raised. The mean plasma myoglobin: FABP ratio differed less than $16 \%$ from the plasma reference ratio of $5 \cdot 1$. In addition a one-compartment model for circulating FABP was validated in dogs. ${ }^{27}$

For each patient measured plasma FABP concentrations and enzyme activities were corrected by subtraction of the normal steadystate values. For this we used the respective plasma reference values (give above) or the concentration or activity measured in the first plasma sample taken from the patient when this value was lower than the reference value.

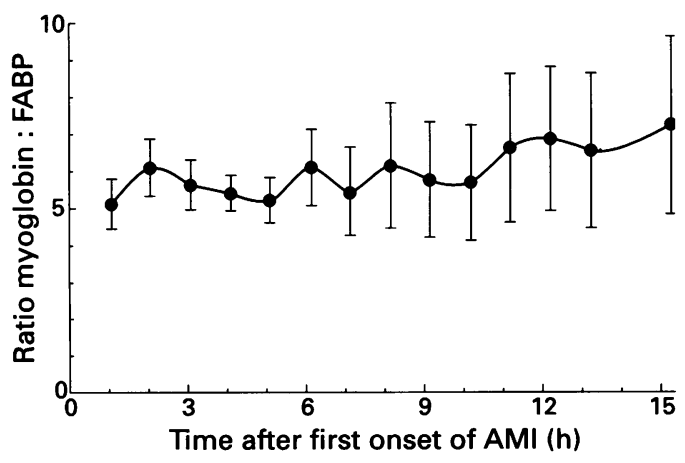

Figure 1 Plasma myoglobin: FABP ratio as a function of time after $A M I$ in 10 patients from whom hourly plasma samples were obtained (mean (SEM). AMI, acute myocardial infarction; FABP, fatty-acid-binding protein. 
Inclusion of patients who presented up to six hours after onset of pain introduced an error into the calculation of the cumulative release of FABP because it ignored prior release. However, only one patient entered the study more than $4.8 \mathrm{~h}$ after the onset of $\mathrm{AMI}$, and in the absence of thrombolysisinduced reperfusion the release of cardiac proteins up to $4.8 \mathrm{~h}$ is relatively small.

\section{MYOCARDIAL INFARCT SIZE}

The cumulative release of each cardiac protein per litre of plasma was divided by the myocardial content of the specific protein per gram of wet weight tissue, so that myocardial injury could be expressed as gram equivalents of healthy heart muscle per litre of plasma. The myocardial content of FABP was measured in parts of intact human heart (left ventricular tissue) obtained from either the De Wever Hospital in Heerlen or the Academic Hospital Maastricht after necropsy (performed within 12 hours after death) on patients who died from non-cardiac causes. FABP content, assayed by the same method as used for plasma, was $0.56(0.07) \mathrm{mg} / \mathrm{g}$ wet weight (mean (SD) for 17 individuals). Regional and transmural differences in the left ventricle were not significant (data not shown). Myocardial enzyme content, measured under the same assay conditions as plasma in the present study, were $132 \mathrm{U} / \mathrm{g}$ for CK-MB ${ }^{28}$ and $123 \mathrm{U} / \mathrm{g}$ for $\mathrm{HBDH} .{ }^{29}$

\section{VALIDATION OF SAMPLING PROTOCOI}

We validated the present sampling protocol for calculation of the cumulative release of FABP in the 10 patients (one woman, nine men; age 45-75) referred to earlier, in whom hourly plasma samples were obtained up to 12 hours after admission to hospital. (About $80 \%$ of total FABP release is completed at this time). The cumulative protein release calculated on the basis of samples obtained at zero, three, six, nine and 12 hours after admission to hospital correlated significantly with the release calculated on the basis of all 13 samples (fig 2) $(r=0.97, \mathrm{p}<0.05)$, indicating that the less frequent sampling protocol will yield good estimates of cumulative protein release.

STATISTICAL ANALYSIS

The release curves for proteins into plasma are presented as means (SEM). Statistical

Figure 2 Relation between the cumulative release over 14 hours (Q14) of FABP into plasma as calculated from plasma concentrations from 5 (3-hourly) or 13 (hourly) blood samples. The line of identity is given (dotted line). The calculated regression line (solid line) is $y=0.96$ $x+0 \cdot 07$. FABP, fattyacid-binding protein.

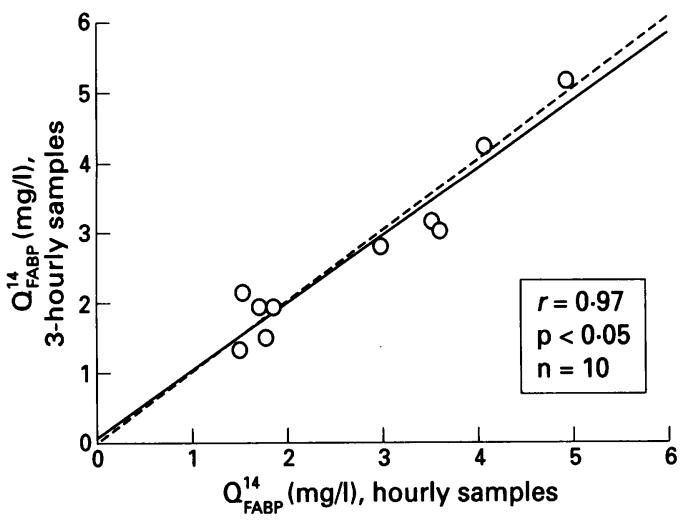

analysis of differences (between groups) was performed with Student's $t$-test. The level of significance was set at $\mathrm{p}<0.05$.

\section{Results}

Mean plasma concentration or activities of the three proteins examined as a function of time for 49 patients (fig 3) showed a large difference between the plasma kinetics of FABP and those of CK-MB and HBDH. The peak plasma concentration FABP was reached $5 \cdot 7$ $(1.4) \mathrm{h}$ after AMI, whereas that of CK-MB was reached $11.7(4.4) \mathrm{h}$ after AMI and that of $\mathrm{HBDH} 28.2(13.5) \mathrm{h}$ after AMI (mean (SD), $n=49$ ). Within 24 hours the plasma concentration of FABP had returned to normal, whereas CK-MB took 50-70 hours and $\mathrm{HBDH}$ more than 70 hours (fig 3 ).

In one patient a recurrent myocardial infarction developed soon $(<10 \mathrm{~h})$ after the initial AMI. The appearance of this recurrent infarction is reflected clearly in the plasma curve for FABP but is less apparent from the $\mathrm{CK}-\mathrm{MB}$ and $\mathrm{HBDH}$ plasma curves (fig 4).

The cumulative release patterns of the three proteins, expressed in gram equivalents of tissue per litre of plasma, also show a difference between FABP and CK-MB and HBDH

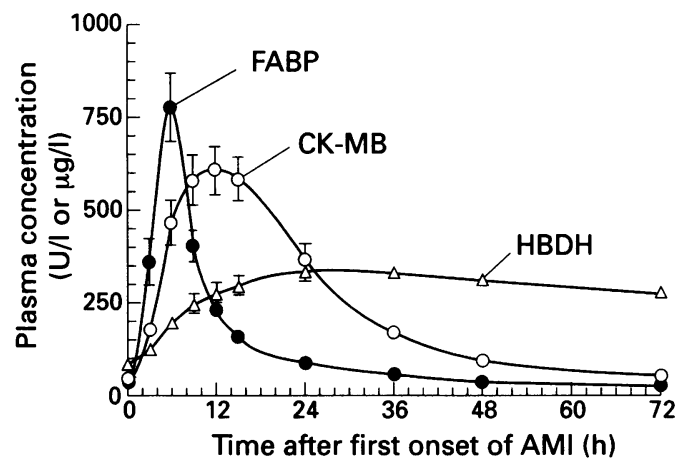

Figure 3 Plasma concentration of $F A B P(\times 5)$ and plasma activities of $C K-M B(\times 10)$ and $H B D H$ as a function of time after AMI in forty-nine patients (mean (SEM). AMI, acute myocardial infarction; $C K-M B$, creatine kinase isoenzyme-MB; $F A B P$, fatty-acid-binding protein; $H B D H$, hydroxybutyrate dehydrogenase.

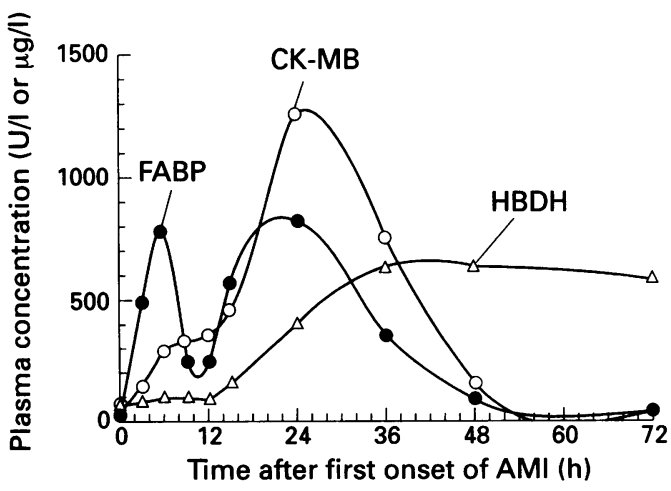

Figure 4 Plasma concentration of FABP $(\times 5)$ and plasma activities of $C K-M B(\times 10)$ and $H B D H$ as a function of time after initial $A M I$ in a patient in whom $A M I$ recurred. AMI, acute myocardial infarction; $C K$ $M B$, creatine kinase isoenzyme-MB; $F A B P$, fatty acidbinding protein; $H B D H$, hydroxybutyrate dehydrogenase. 
Figure 5 Cumulative release of $F A B P, C K-M B$, and $H B D H$ in plasma after $A M I$ in forty-nine patients. Data are expressed in gram equivalents of healthy myocardium per litre of plasma (mean (SEM)) ${ }_{\star}^{\star}$ Cumulative release of $F A B P$ significantly higher $(p<0.05)$ than that of both $C K-M B$ and HBDH. AMI, acute myocardial infarction, $C K-M B$, creatine kinas isoenzyme-MB; FABP, fatty-acid-binding protein $H B D H$, hydroxybutyrate dehydrogenase.

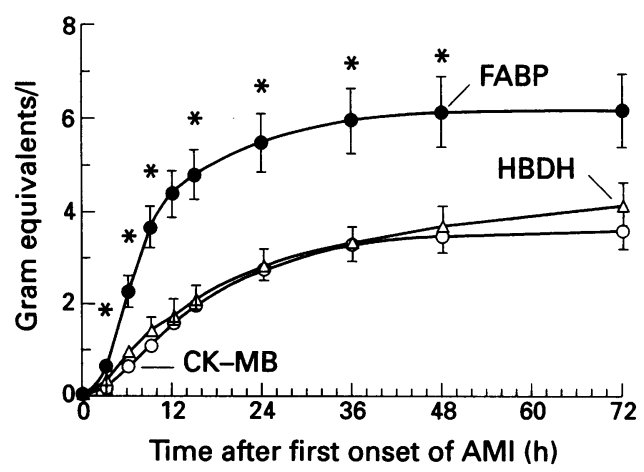

(fig 5). Release of FABP seemed to occur and be completed much earlier than that of either $\mathrm{CK}-\mathrm{MB}$ and $\mathrm{HBDH}$. For instance, $12 \mathrm{~h}$ after AMI about $75 \%$ of the total amount of FABP that was eventually released had appeared in plasma, but only $42 \%$ of CK-MB and $\mathrm{HBDH}$ (fig 5). Total release of FABP was virtually complete 24-36 h after AMI, but that of CK$\mathrm{MB}$ took about $50 \mathrm{~h}$ and that of $\mathrm{HBDH}$ more than $70 \mathrm{~h}$. Despite this kinetic difference, for each of the three proteins the released total quantities yielded comparable estimates of the mean extent of injury when evaluated at $72 \mathrm{~h}$ after the onset of AMI (fig 5).

\section{Discussion}

The rationale for using fatty-acid-binding protein (FABP) as a plasma marker for myocardial injury is based on this soluble protein being present in the myocardium in large amounts and its virtual confinement to the cytoplasmic space. FABP has also been detected in the matrix of bovine heart mitochondria, ${ }^{3031}$ but total mitochondrial FABP represents less than $1 \%$ of the cellular content. $^{30}$ Earlier studies ${ }^{15} 1819$ showed that in humans plasma FABP concentrations increased significantly with ischaemic myocardial injury and, hence, that FABP was a useful qualitative index for the assessment or exclusion of acute myocardial infarction. In the present study we found that the release of FABP from damaged tissue was essentially complete within 36 hours after the onset of $\mathrm{AMI}$ and that the cumulative release of FABP into plasma can be used to estimate myocardial infarct size.

\section{PLASMA KINETICS OF FABP}

For the calculation of cumulative release we assumed that the plasma kinetics of FABP were similar to those of myoglobin. This implies that the elimination of these proteins from plasma can be described with a onecompartment (that is, a plasma volume) model, because their plasma kinetics are dominated entirely by the high rate of protein elimination from plasma so that extravasation can be neglected. ${ }^{21}$ Even if there were significant extravasation of FABP, this would affect only the shape of the release curve and, provided that a full curve is recorded, not the cumulative release over time, which is the variable of interest.
The conclusion that FABP, like myoglobin, is eliminated from plasma predominantly by rapid renal clearance is supported by the reported detection of FABP in urine samples collected as early as two hours after onset of chest pain. ${ }^{19}$

RECOVERY OF FABP IN PLASMA AFTER ISCHAEMIC MYOCARDIAL DAMAGE The total quantities of $\mathrm{CK}-\mathrm{MB}$ and $\mathrm{HBDH}$ depleted from dog heart after coronary occlusion equal the calculated release of these proteins into plasma. ${ }^{32}$ The recovery of FABP in plasma after ischaemic myocardial injury has not yet been measured in experimental studies. In view of the stability of CK-MB and $\mathrm{HBDH}^{29}$ it is generally assumed that in humans too these cardiac proteins are quantitatively recovered in plasma after AMI. The fact that in the present study the estimate of infarct size (expressed in gram equivalents of healthy myocardium) based on cumulative release of FABP resemble estimates based on cumulative release of $\mathrm{CK}-\mathrm{MB}$ or $\mathrm{HBDH}$ suggests that the recovery in plasma of FABP depleted from the heart is also essentially complete.

Release of FABP was completed earlier than that of the two enzymatic markers. The relative delay in the appearance of the enzymes in plasma may relate either to a slower release of enzymes from damaged myocardial cells or a slower transport from the interstitial space to the vascular space by lymph drainage and by increased transendothelial transport in the diseased tissue. There is evidence of binding of cytoplasmic creatine kinase to structural elements in heart muscle. ${ }^{33}$ However, a delay in the interstitial or transendothelial transport of enzymes appears most likely, because experimental studies with isolated rat hearts subjected to low-flow ischaemia and reperfusion showed no differences in the release pattern of various cardiac proteins. ${ }^{34}$ Because CK-MB $(80 \mathrm{kDa})$ and $\mathrm{HBDH}(130 \mathrm{kDa})$ are much larger than FABP $(15.0 \mathrm{kDa})$ it is tempting to suggest that molecular size may well be a main determinant of the rate of protein transport from the interstitial space to the plasma space.

ESTIMATION OF INFARCT SIZE

Estimates of infarct size $72 \mathrm{~h}$ after the onset of AMI based on the various markers were not significantly different (fig 5). However, infarct size calculated from the cumulative release of FABP tended to be higher. This tendency may have been caused by an underestimation of the myocardial content of FABP, but the presently measured value $(0.56 \mathrm{mg} / \mathrm{g})$ was assayed by the same method as used for plasma and is similar to that published by others $\left(0.6 \mathrm{mg} / \mathrm{g} .{ }^{35}\right)$ The difference may also be due to an overestimation of the fractional clearance rate of FABP, which was taken to equal that of myoglobin. The difference in the isoelectric points of FABP (pI 5.1) and myoglobin (pI 7.0) means that at physiological pH FABP is more negatively charged, causing FABP to be cleared less rapidly by 
the kidneys and hence to stay longer in the circulation than myoglobin. ${ }^{36}$ This would lead to a lower fractional clearance rate and in turn to lower values of calculated infarct size.

Alternatively, infarct sizes calculated from the cumulative release of CK-MB and $\mathrm{HBDH}$ in plasma might have been underestimated because these enzymes were measured as activity whereas FABP was measured by an immunochemical assay (that is, as protein mass). Measurement of CK-MB in plasma as protein mass was more reliable than measurement as activity. ${ }^{37}$

Despite these uncertainties we conclude that, provided frequent blood samples are taken, FABP gives a clinically useful estimate of myocardial infarct size, because $72 \mathrm{~h}$ after the onset of AMI we found no significant differences between the estimates based on the various markers.

\section{CLINICAL APPLICATION}

As a plasma marker for ischaemic myocardial injury FABP shares several characteristics with other cardiac proteins (myoglobin, troponin $T$ ) and with cardiospecific enzymes (CK-MB, HBDH), but it also shows some unique differences that will enhance the detection and evaluation of an acute myocardial infarction. Like myoglobin, the rapid appearance of FABP in plasma after tissue damage permits the early assessment of exclusion of $\mathrm{AMI}^{18}$ as well as the immunohistochemical confirmation of very recent myocardial infarction. ${ }^{38}$ This application is also enhanced by the relatively rapid elimination of FABP from plasma because this keeps the steady state plasma concentration of this protein at a low level. A further example of this concept is the fact that the ratio of the cytoplasmic to the vascular concentration of FABP (amounting to about $2 \times 10^{5}$ ) is one order of magnitude higher than that of any of the cardiac enzymes (CK-MB, $6 \times 10^{4}$; $\left.\mathrm{HBDH}, 5 \times 10^{3}\right)$. The consequence of such a high ratio is that the release of only minute amounts of FABP from myocardial cells with significantly raise its plasma concentration, making FABP a diagnostic marker with high sensitivity. Furthermore, the rapid clearance of FABP also allows recurrent infarctions to be more easily identified.

Despite the occurrence of various types of FABP, with some types found solely in a single tissue-such as intestinal FABP in interstitial epithelial cells ${ }^{39} 40$ - heart-type FABP is found not only in cardiac muscle but, like myoglobin, also in striated skeletal muscle. ${ }^{4142}$ However, the myoglobin:FABP ratio of human skeletal muscle is $32-70$ (depending on the muscle fibre type composition) and that of heart $4.9(1.2),{ }^{42}$ making FABP more cardiospecific than myoglobin. Because FABP and myoglobin show similar patterns of release from tissue and of elimination from plasma, the plasma myoglobin:FABP ratio will allow discrimination between cardiac and skeletal muscle damage. ${ }^{42}$

Another condition that may cause erroneous values of plasma FABP (and of myoglo- bin) is a decreased glomerular filtration rate (GFR). In such cases the FABP released from damaged myocardial tissue will accumulate in the plasma, ${ }^{18}$ thus leading to a possible overestimation of infarct size.

The rapid release of FABP into plasma makes possible a reliable measure of myocardial infarct size within 24 hours of AMI. However, this application must meet two conditions. First, sufficient plasma samples have to be obtained during the first day of hospital admission. Secondly, the use of the FABP plasma concentration as an early diagnostic tool of AMI requires a fast assay system. This is not yet available (the sandwich ELISA used in the present study takes a few hours to complete), but recent developments with immunodiagnostic tests ${ }^{43}$ should lead to a sensitive assay for plasma FABP that will give quantitative data within minutes. In addition, immunochemical detection of biochemical plasma markers is generally considered to have the advantage of being free from problems inherent to the measurement of enzyme activity of proteins.

We thank Prof Dr M L Simoons, Department of Cardiology and Thoraxcenter, University Hospital Dijkzigt, Rotterdam, The Netherlands, for his interest and valuable advice. This study was supported by StiPT, Executive Agency for Technology Policy (MTR 88002). J F C G is an Established Investigator of the Netherlands Heart Foundation.

1 Willems GM, Muijtiens AMM, Lambi FHH, Hermens WTh. Estimation of circulatory parameters in patients with acute myocardial infarction. Significance for calcuwith acute myocardial infarction. Significance for calculation of

2 Van der Veen FH, Visser R, Willems GM, Kop-Klaassen B, Hermens WTh. Myocardial enzyme depletion in infarcted human hearts: infarct size and equivalent tissue mass. Cardiovasc Res 1988;22:611-9.

3 Stone MJ, Waterman MR, Harimoto D, Murray G, Wilson N, Platt MR, et al. Serum myoglobin level as diagnostic test in patients with acute myocardial infarction. Br Heart f 1977;39:375-80.

4 McComb JM, McMaster EA, MacKenzie G, Adgey AAJ. Myoglobin and creatine kinase in acute myocardial infarction. Br Heart $\mathcal{f} 1984 ; 51: 189-94$.

5 Katus HA, Remppis A, Looser S, Hallermeier K, Scheffold T, Kübler W. Enzyme-linked immuno assay of cardiac troponin $\mathrm{T}$ for the detection of acute myocardia infarction in patients. $f \mathrm{Mol}$ Cell Cardiol 1989;21: 1349-53.

6 Katus HA, Looser S, Hallermeier K, Remppis A Scheffold T, Borgya A, et al. Development and in vitro characterization of a new immunoassay of cardiac troponin T. Clin Chem 1992;38:386-93.

7 Hangaard J, Rasmussen O, Norregaard Hanssen K, Jorgensen N, Simonsen EE, Norgaard-Pedersen B. Early diagnosis of acute myocardial infarction with a rapid latex agglutination test for semi-quantitative estimation of serum myoglobin. Acta Med Scand 1987;221:343-8.

8 Mair J, Artner-Dworzak E, Lechleitner P, Morass B, Smidt J, Wagner I, et al. Early diagnosis of acute myocardial infarction by a newly developed rapid immunoturbidimetric assay for myoglobin. Br Heart $\mathcal{f}$ 1992;68:462-8.

9 Ellis KA, Litle T, Masud Z, Liberman HA, Morris DC Klocke FJ. Early noninvasive detection of successfu reperfusion in patients with acute myocardial infarction Circulation 1988;78:1352-7.

10 Katus HA, Diederich KW, Scheffold $T$, Uellner $M$, Schwarz F, Kübler W. Non-invasive assessment of infarct reperfusion: the predictive power of the time to peak value of myoglobin, CK-MB and CK in serum. Eur peak value of myoglobin,

11 De Zwaan Ch, Willems GM, Vermeer F, Res J, Verheugt FWA, Van der Laarse A, et al. Enzyme tests in the FWA, Van der Laarse A, et al. Enzyme tests in the evaluation of thrombolysis in act
tion. Br Heart $\mathcal{f} 1988 ; 59: 175-83$.

12 Delanghe JR, De Buyzere ML, Cluyse LP, Thierens HM, Clement DL. Acute myocardial infarction size and myoglobin release into serum. Eur $\mathrm{f}$ Clin Chem Clin Biochem 1992;30:823-30.

13 Glatz JFC, Van Bilsen M, Paulussen RJA, Veerkamp JH, Van der Vusse GJ, Reneman RS. Release of fatty acidbinding protein from isolated rat heart subjected to ischemia and reperfusion or to the calcium paradox. Biochim Biophys Acta 1988;961:148-52.

14 Knowlton AA, Apstein CS, Saouf R, Brecher P. Leakage 
of heart fatty acid-binding protein with ischemia and reperfusion in the rat. $\mathcal{f}$ Mol Cell Cardiol 1989;21: 577-83.

15 Knowlton AA, Burrier RE, Brecher P. Rabbit heart fatty acid-binding protein. Isolation, characterization, and application of a monoclonal antibody. Circ Res 1989; 65:981-8.

16 Glatz JFC, Van der Vusse GJ. Cellular fatty acid-binding proteins: Current concepts and

17 Veerkamp JH, Peeters RA, Maatman RGHJ. Structural and functional features of different types of cytoplasmic fatty acid-binding proteins. Biochim Biophys Acta fatty acid-binding

18 Kleine AH, Glatz JFC, Van Nieuwenhoven FA, Van der Vusse GJ. Release of heart fatty acid-binding protein Vusse GJ. Release of heart fatty acid-binding protein into plasma after acute myocardial
$M o l$
Cell Biochem 1992;116:155-62.

19 Tanaka T, Hirota Y, Sohmiya K-I, Nishimura S, Kawamura K. Serum and urinary heart fatty acid-binding protein in acute myocardial infarction. Clin Biochem 1991;24:195-201.

20 Van der Wieken LR, Nijssen KM, Simoons ML. Ridogrel as an adjunct to thrombolysis in acute myocardial infarction. Eur Heart $\mathcal{f}$ (in press)

21 Willems GM, Visser MP, Krill MTA, Hermens WTh. Quantitative analysis of plasma enzyme levels based on simultaneous determination of different enzymes. Cardiovasc Res 1982;16:120-31.

22 Sylvèn $C$. The kinetics of myoglobin in old volunteers and in patients with acute myocardial infarction. Scand $\mathcal{F}$ Clin in patients with acute myo

23 Groth T, Sylvèn C. Myoglobin kinetics in patients suffering from acute myocardial infarction in its early phase-as from acute myocardial infarction in its early phase-as
studied by the single injection method. Scand $f$ Clin Lab studied by the single inje

24 Hansen NE, Karle H, Andersen V, Ølgaard K. Lysozyme turnover in man. 7 Clin Invest 1972;51:1146-55.

25 Vahlquist A, Peterson PA, Wibell L. Metabolism of the vitamin A transporting protein complex. Eur $\mathcal{f}$ Clin Invest 1973;3:352-62.

26 Ellis AK, Saran BR. Kinetics of myoglobin release and prediction of myocardial depletion after coronary artery reperfusion. Circulation 1989;80:676-83.

27 Tsuji R, Tanaka T, Somiya K, Yoshimoto K, Hirota Y, Kawamura $K$. Canine heart fatty acid-binding protein (ch-FABP). Purification and kinetic studies [abstr]. f Mol Cell Cardiol 1992;24:S183.

28 Hermens WTh, Willems GM, Davids HA, Hollaar L, Van der Laarse A. Enzymatic assessment of myocardial injury after infarction or cardiac surgery. Is isozyme injury after infarction or cardiac surgery. Is isozym

29 Van der Laarse A, Dijkshoorn NJ, Hollaar L, Caspers T. The (iso-)enzyme activities of lactate dehydrogenase, The (iso-)enzyme activities of lactate dehydrogenase, alphahydroxybutyrate dehydrogenase, creatine kinase biopsies and autopsies. Clin Chim Acta 1980;104: biopsies
30 Börchers T, Unterberg C, Rüdel H, Robenek H, Spener F. Subcellular distribution of cardiac fatty acid-binding protein in bovine heart muscle and quantitation with an enzyme-linked immunosorbent assay. Biochim Biophys Acta 1989;1002:54-61.

31 Unterberg C, Börchers T, Hojrup P, Roepstorff $P$, Knudsen J, Spener F. Cardiac fatty acid-binding proteins. Isolation and characterization of the mitochondrial fatty acid-binding protein and its structural relationship with the cytosolic isoforms. F Biol Chem 1990;265. $16255-61$.

32 Hermens WT, Van der Veen FH, Willems GM, MullersBoumans ML, Schrijvers-Van Schendel A, Reneman RS. Complete recovery in plasma of enzymes lost from the heart after permanent coronary occlusion in the dog. Circulation 1990;81:649-59.

33 Ottaway JH. Evidence for binding of cytoplasmic creatine kinase to structural elements in heart muscle. Nature 1967;215:521-2.

34 Vork MM, Glatz JFC, Surtel DAM, Van der Vusse GJ. Protein release from isolated rat heart during normoxia, low-flow ischemia and reperfusion. Can $\mathcal{f}$ Physiol Pharmacol (in press).

35 Paulussen RJA, Van Moerkerk HTB, Veerkamp JH Immunochemical quantitation of fatty acid-binding proteins. Tissue distribution of liver and heart FABP types in human and porcine tissues. Int $\mathcal{F}$ Biochem 1990; 22:393-8.

36 Guyton AC Glomerular filtration and glomerular filtrate. In: Wonsiewicz MJ, ed. Textbook of medical physiology. Philadelphia: Saunders, 1991:290-7.

37 Eisenberg PR, Shaw D, Schaab C, Jaffe AS. Concordance of creatine kinase-MB activity and mass. Clin Chem of creatine kinas

38 Kleine AH, Glatz JFC, Havenith MG, Van Nieuwenhoven FA, Van der Vusse GJ, Bosman FT. ImmunoFA, Van der Vusse GJ, Bosman FT. Immunohistochemical detection of very recent myocardial infarctions in humans with antibodies against heart-type fa
acid-binding protein. Cardiovasc Pathol 1993;2:63-9.

39 Sacchettini JC, Hauft SM, Van Camp SL, Cistola DP Gordon JI. Development and structural studies of an intracellular lipid binding protein in the ileal epithelium f Biol Chem 1990;265:19199-207.

40 Kanda $T$, Nakatomi $Y$, Ishikawa $H$, Hitomi $M$, Matsubara $\mathrm{Y}$, Ono $\mathrm{T}$, et al. Intestinal fatty acid-binding protein as a sensitive marker of intestinal ischemia. Digest Dis $S c i$ 1992;37:1362-7.

41 Peeters RA, Veerkamp JH, Van Kessel AG, Kanda T, Ono $T$. Cloning of the CDNA encoding human skeletal muscle fatty acid-binding protein, its peptide sequence and chromosomal localization. Biochem $\mathcal{f}$ 1991;276:203-7.

42 Van Nieuwenhoven FA, Kleine AH, Keizer HA, Van Dieijen-Visser MP, Van der Vusse GJ, Glatz JFC. Comparison of myoglobin and fatty acid-binding protein as plasma markers for muscle damage in man [abstr]. as plasma markers for muscle

43 Newman JD. Turner APF. Biosensors: principles and practice. Essays Biochem 1992;27:147-59. 